Columbia Law School

Scholarship Archive

2003

\title{
Harnessing Information Technology to Improve the Environmental Impact Review Process
}

\author{
Michael B. Gerrard \\ Columbia Law School, michael.gerrard@law.columbia.edu \\ Michael Herz
}

Follow this and additional works at: https://scholarship.law.columbia.edu/faculty_scholarship

Part of the Computer Law Commons, Environmental Law Commons, and the Science and Technology Law Commons

\section{Recommended Citation}

Michael B. Gerrard \& Michael Herz, Harnessing Information Technology to Improve the Environmental Impact Review Process, 12 N.Y.U. ENVTL. L. J. 18 (2003).

Available at: https://scholarship.law.columbia.edu/faculty_scholarship/696

This Article is brought to you for free and open access by the Faculty Publications at Scholarship Archive. It has been accepted for inclusion in Faculty Scholarship by an authorized administrator of Scholarship Archive. For more information, please contact scholarshiparchive@law.columbia.edu. 


\title{
HARNESSING INFORMATION TECHNOLOGY TO IMPROVE THE ENVIRONMENTAL IMPACT REVIEW PROCESS
}

\author{
Michael B. GerRarD* \& Michael Herz ${ }^{* *}$
}

TABLE OF CONTENTS

Introduction

I. Environmental Documents and the Internet

A. Drawbacks of the Hard Copy Environmental Impact

Statement.................................................................... 22

1. Accessibility and Expense ....................................... 22

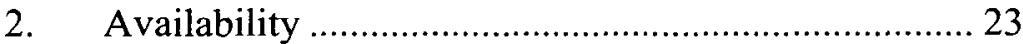

3. Finding Information Within an Environmental

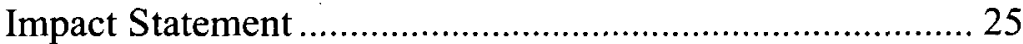

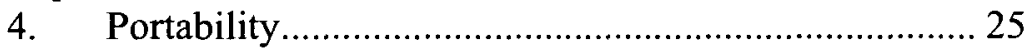

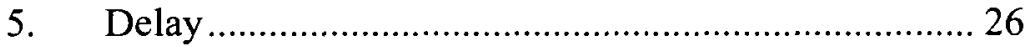

6. Environmental Impact Statements as Self-Contained, Isolated Documents ............................................................ 26

B. Advantages of the Online Environmental Impact

Statement.......................................................................... 27

C. Current Practice........................................................... 30

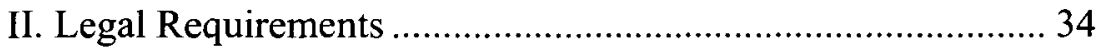

A. National Environmental Policy Act .............................. 34

B. The Paperwork Reduction Act...................................... 39

C. The Electronic Freedom of Information Act................... 42

D. The E-Government Act of 2002 .................................... 44

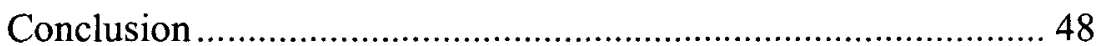

* Partner, Arnold \& Porter, New York, NY; J.D., 1978, New York University School of Law.

** Professor of Law, Cardozo School of Law, Yeshiva University; J.D., 1982, University of Chicago Law School. The authors would like to thank Joni Kletter and Michele Filorimo, Cardozo School of Law '04, for helpful research assistance. 


\section{INTRODUCTION}

In 1970, when the National Environmental Policy Act $^{1}$ (NEPA) was enacted, the new and exciting information management technologies were the handheld four-function calculator and the eight-track tape cassette. Three decades later, after the personal computer, the digital revolution, and the World Wide Web, the implementation of NEPA is still stuck in the world of 1970 . Other aspects of the bureaucracy have seen reform-the E-Government Strategy, ${ }^{2}$ an E-Government Act, ${ }^{3}$ the creation of a new Office of Electronic Government within the Office of Management and Budget (OMB), ${ }^{4}$ and, to focus on the environmental arena, the breathtaking success of the web-based Toxic Release Inventory. ${ }^{5}$ Yet the storage and dissemination of environmental impact review documents continue on the original, emphatically non-electronic, model. This Article suggests several improvements that can and indeed must be made to the environmental impact review process in light of both the technological and legal developments of the last thirty years.

\section{I}

\section{ENVIRONMENTAL DOCUMENTS AND THE INTERNET}

The principal requirement of NEPA is that an environmental impact statement (EIS) must be prepared for major federal actions

1 National Environmental Policy Act of 1969, Pub L. No. 91-190, 83 Stat. 852 (1970) (codified as amended at 42 U.S.C. $\$ \S 4321-4370(f)(2000)$ ).

2 See EXECUTIVE OfFICE OF THE PRESIDENT OF THE U.S., IMPLEMENTING THE PRESIDENT'S MANAGEMENT AGENDA FOR E-GOVERNMENT: E-GOVERNMENT STRATEGY (2003) (describing successes and challenges in electronic government) [hereinafter E-GOVERNMENT STRATEGY], http://www.cio.gov/ documents/2003egov_strat.pdf.

3 E-Government Act of 2002, Pub. L. No. 107-347, 116 Stat. 2899 (codified in scattered sections of 44 U.S.C.A. (West 2003)).

444 U.S.C.A. $\$ 3602$.

5 See generally Bradley C. Karkkainen, Information as Environmental Regulation: TRI and Performance Benchmarking, Precursor To a New Paradigm?, 89 GEo. L.J. 257 (2001). The Toxic Release Inventory (TRI) "require[d] facilities that meet minimum size and emission thresholds to report, on standardized forms, their annual releases of listed toxic pollutants." Id. at 259. It was a good idea that became a great one because of the perfectly timed development of the ideal tool for dissemination of TRI data: the World Wide Web. 
that may have a significant effect on the human environment. ${ }^{6}$ Unless a particular action falls within a category that agency regulations identify as either always or never requiring an EIS, an agency considering an action must first determine whether an EIS is necessary by preparing an environmental assessment (EA). ${ }^{7}$ If the agency finds, on the basis of the EA, that the action will not have a significant environmental impact, it makes a finding of no significant impact (FONSI), ${ }^{8}$ and the environmental review process comes to a close. If the EA indicates an EIS is necessary, the agency must first prepare a draft EIS (DEIS), ${ }^{9}$ on which it receives comments from the United States Environmental Protection Agency (EPA), other relevant state and federal agencies, affected parties, and members of the public. ${ }^{10}$ It then issues a final EIS (FEIS), ${ }^{11}$ in which it responds to those comments and modifies the DEIS as necessary, along with a record of decision (ROD) that summarizes the decision made, the alternatives rejected, and the steps taken to minimize environmental impacts. ${ }^{12}$ As a group, the EA, FONSI, DEIS, FEIS, and ROD are referred to as "environmental documents."13

642 U.S.C. $\S 4332(2)(C)$. This "detailed statement" must address "the environmental impact of the proposed action," any unavoidable adverse environmental impacts, "alternatives to the proposed action," the "relationship between local short-term uses of [the] environment and the maintenance and enhancement of long-term productivity," and "any irreversible and irretrievable commitments of resources which would be involved in the proposed action should it be implemented." Id.

7 Council on Environmental Quality NEPA Regulations, 40 C.F.R. $\S$ 1501.4(a)-(c) (2003). An EA is defined by 40 C.F.R. $\S 1508.9$.

840 C.F.R. $\S 1501.4(\mathrm{e})$. A FONSI is defined by 40 C.F.R. $\S 1508.13$.

940 C.F.R. $\$ 1502.9$ (a).

1040 C.F.R. $\$ 1503.1$.

1140 C.F.R. $\$ 1502.9(\mathrm{~b})$.

1240 C.F.R. $\S 1505.2$.

13 See, e.g., 40 C.F.R. $\S 1501.2(\mathrm{~b})$. The literature on NEPA is voluminous, with many useful summaries and assessments. See, e.g., ENVIRONMENTAL Policy and NEPA: PAST, PResent AND Future (Ray Clark \& Larry Canter eds., 1997) [hereinafter ENVIRONMENTAL POLICY AND NEPA]; DANIEL R. MandelKer, NEPA LaW \& Litigation (2d ed. 1992); SERGE TAYlor, MaKING BurEaUCRACIES THINK: THE ENVIRONMENTAL IMPACT STATEMENT STRATEGY OF ADMINISTRATIVE REFORM (1984); Sharon Buccino, NEPA Under Assault: Congressional and Admininstrative Proposals Would Weaken Environmental Review and Public Participation, 12 N.Y.U. ENVTL. L.J. 50 (2003); James T.B. Tripp \& Nathan G. Alley, Streamlining NEPA's Environmental Review Process: Suggestions for Agency Reform, 12 N.Y.U. ENVTL. L.J. 74 (2003); Bradley C. Karkkainen, Toward a Smarter NEPA: Monitoring and Managing Government's 
A number of states have adopted so-called "mini-NEPAs" that largely resemble the federal statute. Of these, the most advanced, detailed, and frequently litigated, are the New York State Environmental Quality Review Act (SEQRA), ${ }^{14}$ California Environmental Quality Act (CEQA), ${ }^{15}$ and Washington Environmental Policy Act. ${ }^{16}$ Although some of the details, reach, and acronyms vary significantly among the mini-NEPAs, their overall approach and resulting documentation are much the same as in the federal scheme.

The EIS was born when the most advanced office equipment was the Selectric typewriter. Word processors did not yet exist, much less the Internet. The entire federal government contained a grand total of only 5,277 computers. ${ }^{17}$ It was a world of the printed page. Thus, EISs were based on the model of the Sears catalog-hard copies of massive paper documents. When Richard W. Sears issued his first catalogue in $1887,{ }^{18}$ he relied heavily on an emergent technology of information dissemination-Rural Free Delivery. ${ }^{19}$ But a little more than a century later his successors abandoned the comprehensive catalogue, concluding that the internet was a far more efficient and less expensive method of selling their goods, and they launched sears.com as their predominant method for out-of-store sales. ${ }^{20}$

Environmental Performance, 102 ColuM. L. REv. 903 (2002); Michael Herz, Parallel Universes: NEPA Lessons for the New Property, 93 CoLUM. L. REV. 1668 (1993).

14 N.Y. ENVTL. CONSERV. LAW $\S \S 8-0101$ to -0117 (McKinney 2003).

15 CAL. PUB. RES. CODE $\S \S 21000-21178.1$ (West 2003).

16 WASH. REV. CODE $\S \S 43.21$ C.010-.914 (1998).

17 S. REP. NO. 104-272, at 8 (1996). The number has since increased almost a thousand fold; federal agencies now use more than four million computers. Memorandum from Mitchell E. Daniels, Jr., OMB Director, to Heads of Departments and Agencies (June 2, 2003), http://www.whitehouse.gov/omb/ memoranda/m03-14.html (last visited Nov. 24, 2003). Thus, the civilian workforce has twice as many computers as people. See OfFICE OF PERS. MGMT., DEMOGRAPHIC PROFILES OF THE FEDERAL WORKFORCE 5 (2001) (reporting that as of September 30,2000, there were $1,755,689$ civilian employees of the federal government), http://www.opm.gov/feddata/demograp/ 00demogr.pdf.

18 SEARS, ROEBUCK \& Co., ANNUAL REPORT (2001) (showing timeline of company history), http://ext.corporate-ir.net/media_files/nys/s/reports/ s_ar2001b.pdf.

19 Daniel J. Boorstin, The Americans: The Democratic Experience 127-29 (1973).

20 SEARS, ROEBUCK \& Co., supra note 18. Appropriately, the company's 2001 Annual Report has on its cover a photograph of a woman sitting at the breakfast table in front of her computer, checking out sears.com, no doubt. 
There is no reason to believe that EIS readers are less computer savvy than Sears customers, yet EISs are still stuck in the technology of 1970. The result is an enormous forgone opportunity to make EISs more effective, usable, and valuable. This Article argues that both sound policy and existing legal requirements obligate federal agencies to post EISs on the web.

\section{A. Drawbacks of the Hard Copy Environmental Impact Statement}

While individual agencies in individual instances have taken advantage of the web to disseminate EISs, most have not. The continued reliance on paper EISs has a number of drawbacks. ${ }^{21}$

\section{Accessibility and Expense}

EISs are typically hundreds or thousands of pages long, with the larger ones divided into several volumes with many oversized and colored maps, charts and other illustrations. As a result they are quite expensive to reproduce and distribute. Thus, for projects that have garnered any degree of public interest, copies cannot be made for everyone who is interested. Instead, people must physically visit a library to review a copy, or pay a copying fee that can easily approach or exceed one hundred dollars. ${ }^{22}$ This significantly reduces actual public access to EISs, especially in an era where library hours are being shortened to fill municipal budget gaps, ${ }^{23}$ and people have little time to visit libraries anyway.

The very process of writing an EIS serves one core function of NEPA, which is to inform the agency prior to its taking a proposed action. ${ }^{24}$ But while a completed EIS that sits in an agency office or reading room may be meaningfully available to agency personnel in that office, informing select agency personnel

21 For similar critiques and assessments, see E.J. Koford, Environmental Impact Reports on the Internet, ENVTL. MONITOR, Apr. 7, 1996, at http://ceres.ca.gov/planning/ead/CEQA_net.html; Robert Twiss, Why Environmental Documents Should $\bar{B}$ e Digital and On-Line (1996), at http://www.regis.berkeley.edu/whyeir2.html.

22 Twiss, supra note 21.

23 See, e.g., Alexander Reid, Emotions Rise as Vote on Tax Nears, Boston Globe (Northwest), June 5, 2003, at 1.

${ }^{24}$ See 40 C.F.R. $\$ 1502.1$ (2003) (The EIS "shall provide full and fair discussion of significant environmental impacts and shall inform decisionmakers and the public of the reasonable alternatives which would avoid or minimize adverse impacts or enhance the quality of the human environment."). 
is not the sole function of the EIS process. NEPA documents and the information generated in their production can be important to other decisionmakers and to the world at large. Even within the agency, information should be made as available and accessible as possible. An agency employee in a different section, or who arrives five years after an EIS is completed, may be unaware of what has been done and where it can be found. Most important, one of the ways in which preparation of an EIS informs the agency is through the process of public comment. ${ }^{25}$ Effective public comment in turn depends on the ready and timely availability of documents upon which to comment. ${ }^{26}$

\section{Availability}

In one sense EISs have proven "ephemeral" despite their enormous bulk ${ }^{27}$ - once produced, they seem almost to evaporate. Simply because they are so big, it is expensive to store many of them. Sooner or later, the preparing agency will just toss the old ones. $^{28}$ The Council on Environmental Quality (CEQ) receives all NEPA EISs, but it does not maintain them in any sort of library. ${ }^{29}$ EPA must comment on most DEISs, ${ }^{30}$ but it maintains only a limited historical library. ${ }^{31}$ The most comprehensive collection of

25 See id. $\$ 1503.1$.

26 As the Supreme Court has written:

Section $102(2)(C)$ thus serves twin aims. The first is to inject environmental considerations into the federal agency's decisionmaking process by requiring the agency to prepare an EIS. The second aim is to inform the public that the agency has considered environmental concerns in its decisionmaking process. Through the disclosure of an EIS, the public is made aware that the agency has taken environmental considerations into account.

Weinberger v. Catholic Action of Haw./Peace Educ. Project, 454 U.S. 139, 143 (1981).

27 Twiss, supra note 21 (lamenting that " $[\mathrm{u}] \mathrm{nder}$ current practice, environmental documents are ephemeral" because they are not archived).

28 For example, the official policy of the Federal Highway Administration (FHWA) within the Department of Transportation (DOT) is to destroy EISs thirteen years after final approval. See FHWA, DOT, RECORDS DISPOSITION MANUAL ch. 4, at http:/www.fhwa.dot.gov/legsregs/directives/orders/envireg.htm (last visited Nov. 24, 2003). For more information regarding FHWA's handling of records, see FHWA, DOT, FHWA FILES MANAGEMENT AND RecordS Disposition ManUal, FHWA Order No. M 1324.1A (1999), http://www. fhwa.dot.gov/legsregs/directives/orders/m1324.1/m1324la.htm.

2942 U.S.C. $\$ 4332(2)($ C) $(2000)$.

3042 U.S.C. $\$ 7609(2000)$.

31 EPA headquarters in Washington maintains a microfiche collection of 
federal EISs is private, found at the Northwestern University Transportation Library in Evanston, Illinois. Almost all federal EISs dating back to NEPA's inception can be found here, for the most part in both draft and final form, along with other environmental documents. ${ }^{32}$ While this is an extraordinary and comprehensive collection, it is also unique; there is no other place in the United States in which these documents reliably can be found. Individual agencies often have copies of EISs they prepared but not always, and finding an older EIS remains a hit or miss proposition.

The situation is similar at the state level. The New York Department of Environmental Conservation (DEC) by law must be sent copies of all EISs prepared under SEQRA. ${ }^{33}$ Yet DEC does not keep them all. Several years' worth of EISs were lost in a flood at an off-site storage facility, and many more were discarded when DEC moved its headquarters to a new building in Albany in 2001. ${ }^{34}$ California maintains a State Clearinghouse to which are sent all Environmental Impact Reports prepared under CEQA. ${ }^{35}$ Yet "the Clearinghouse has never functioned as either a repository or a library." 36

Finally, many EISs are prepared by private consulting firms. ${ }^{37}$ While these firms generally keep bookcases full of old EISs on which they worked, such collections are, not comprehensive, publicly accessible, catalogued, or unified. Preparation of an EIS is costly-sometimes it requires tens of thousands and sometimes millions of dollars-and involves the compilation of large amounts

final EISs filed from 1970 through 1977 and all draft, final, and supplemental EISs filed from 1978 through 1990 . To view the microfiches, one must either travel to Washington or rely on interlibrary loan-two cumbersome, expensive, and time-consuming options. See EPA, Obtaining Environmental Impact Statements, at http://www.epa.gov/Compliance/nepa/obtaineis/index.html (last visited Nov. 24, 2003).

32 Northwestern Univ. Transp. Library, How to Search for Environmental Impact Statements, at http://www.library.northwestern.edu/transportation/ searcheis.html (last visited Dec. 23, 2003).

33 N.Y. COMP. CODES R. \& REGS. tit. 6, \& 617.12(b)(6) (2001).

34 E-mail from Jack Nasca, Division of Environmental Permits, DEC, to Michael Gerrard, Partner, Arnold \& Porter (Oct. 6, 2003, 16:43:00 EST) (on file with author).

35 Koford, supra note 21.

${ }^{36}$ Id.

37 EIS consulting has become an international business. See, e.g., URS CORP., at http://www.urscorp.com (last visited Dec. 5, 2003). 
of original data about the natural and human environments. Because it is not systematically maintained, this information is often lost forever.

\section{Finding Information Within an Environmental Impact Statement}

EISs always have tables of contents but rarely indexes, so it is often difficult to find a particular piece of information within the document. There is also no master index of EISs, so researchers have no way of knowing - at least not without extraordinary effort-that a particular subject has already been studied in a prior EIS. Thus, the EIS is not a user-friendly document. As the EIS has grown more unwieldy and enormous, it has become less helpful to all but the most determined and sophisticated readers, with a common complaint being that the goal is not so much to inform as to smother. ${ }^{38}$ In order to make an EIS impervious to litigation, "agencies ... overstuff the EIS with information from every available source, regardless of its quality, so as to achieve a protective layer of redundancy or 'overkill' while at the same time inoculating themselves against the charge that they overlooked relevant information." ${ }^{39}$ The resulting difficulties are significantly compounded by the impossibility of doing precise, focused, efficient searches within an EIS. This in turn impedes the ability to comment on a DEIS or to make effective use of an FEIS.

\section{Portability}

EISs are not exactly portable. It is not easy to lug multivolume behemoths from one place to another or to review them while traveling. Indeed, one of the authors recalls a former chair

38 Karkkainen, supra note 13 , at 918.

39 Id. at 922. See also Holly Welles, The CEQ NEPA Effectiveness Study: Learning from Our Past and Shaping Our Future, in ENVIRONMENTAL POLICY AND NEPA, supra note 13, at 201 ("Fear of litigation is commonly cited as the driving force to prepare overly detailed and lengthy EISs."). For a list of decisions under SEQRA in which trial-level courts struck down the environmental review documents for major projects because of perceived omissions of particular information, only to be reversed on appeal, see Michael B. Gerrard \& Monica Jahan Bose, Possible Ways to 'Reform' SEQRA, N.Y. L.J., Jan. 23, 1998, at 3. Such decisions often lead to lengthy and expensive delays in project constructions and induce counsel to advise clients to write long EISs so that no holes can be found. See Tripp \& Alley, supra note 13, at 83; Stewart E. Sterk, Environmental Review in the Land Use Process: New York's Experience with SEQRA, 13 CARDOZO L. REV. 2041, 2081-83 (1992). 
of the New York City Planning Commission throwing her back out and requiring hospitalization after attempting to lift an especially large EIS.

\section{Delay}

The environmental review process, even if it involves only an EA leading to a FONSI rather than a full-fledged EIS, is notoriously lengthy. There are many reasons for this, but part of the problem is the fact that the documents must be produced in hard copy format. Before a DEIS or an FEIS actually reaches the eyes of an interested party, it must be printed, reproduced, and sent by snail mail to a library or other repository. ${ }^{40}$ This occurs at each stage of a multi-stage proceeding, resulting in an ever compounding delay.

\section{Environmental Impact Statements as Self-Contained, Isolated Documents}

CEQA declares it to be the policy of California that "[i]nformation developed in individual environmental impact reports be incorporated into a data base which can be used to reduce delay and duplication in preparation of subsequent environmental impact reports." ${ }^{11}$ This is a noble, and sensible, aspiration. Rather than reinventing the wheel with each EIS, preparers could draw on the work of those who preceded them. For it to come to pass, however, that work must be available and accessible. As this Article has already noted, that is not the case. The database anticipated by the California legislature has never been established; nor is there an equivalent in other states or at the federal level. This has two consequences. First and most obvious, it means a lot of unnecessary work takes place as the authors of EISs reinvent the wheel, duplicating investigations that have already occurred. Second, the absence of a database makes it very difficult to evaluate either an EIS, the project the EIS assesses over time, or to compare the project with other projects. As Bradley Karkkainen has written:

40 Twiss, supra note 21.

41 CAL. PUB. RES. CODE $\S 21003(\mathrm{~d})$ (West 2003). See also id. $\S 21003(\mathrm{e})$ (stating policy that "[i]nformation developed in environmental impact reports and negative declarations be incorporated into a data base which may be used to make subsequent or supplemental environmental determinations"). 
because EISs are produced on a sporadic, ad hoc, and largely project-specific basis, each document is a unique and selfcontained universe of information.... Rarely is it possible to make meaningful comparisons, or to aggregate or synthesize information across multiple EISs, over time, or among agencies with disparate NEPA practices. Because such idiosyncratic documents cannot be used to generate comparative benchmarks, cumulative assessments, or longitudinal analyses of environmental performance trends, EISs create no broader context for evaluating the particular projects they accompany. Nor do they provide the basis for assessments of government's environmental performance in the aggregate and over time. ${ }^{42}$

The EIS is in this way a purely prospective document, the theory being that it will inform a decision yet to be made. Rarely does anyone suggest that it has a significant function after the relevant action has taken place. However, EISs are potentially both valuable and relevant after the fact. First, they contain an enormous amount of information, often compiled at great effort and expense. Second, they describe and rest on certain assumptions about the action itself, predictions about its effects, and undertakings with regard to the mitigation of its impacts. In the real world, much of that is forgotten once the EIS and the project it describes are complete. Only rarely does anyone go back and check whether the impacts that were predicted in an EIS turned out to resemble the impacts that actually occurred. NEPA contains no requirement for post-EIS verification. This failure to review the assumptions and undertakings that led to a project going ahead is not solely the result of the fact that the EIS itself was filed away and forgotten, but that is part of the explanation. Accessible and searchable EISs are a necessary, though not sufficient, condition for meaningful ex post review.

\section{B. Advantages of the Online Environmental Impact Statement}

There is no reason for this situation to persist. Every EIS today is produced on word processing equipment. It is altogether straightforward to submit environmental documents in electronic format and then load them on a server, making them immediately available to the whole world for free. As discussed in the next section, the agencies actually doing so are a distinct minority, but there are enough to demonstrate both the practice's feasibility and

42 Karkkainen, supra note 13 , at 923. 
its usefulness.

Electronic distribution of EISs would significantly improve if not outright eliminate each of the foregoing problems. It would be much less expensive than making and distributing hard copies. The EISs would be immediately available to everyone who wanted them, inside the government and out. Public access to environmental documents through the Internet would enormously enhance the ease of and opportunities for public comment and participation in environmental decision-making.

Preparing an electronic version does take time, to be sure; however, copying and distribution is instantaneous. EISs could be permanently stored with virtually no need for physical storage space. The list of existing electronic EISs would be searchable, so researchers everywhere could learn what subjects have already been studied and what data has been compiled. In preparing EISs for electronic distribution, links could be provided to source material, bibliographic references, analysis methodologies, and other information and data that would be useful to readers.

One objection to the electronic dissemination of official information is the "digital divide"- the fact that many low income people do not have access to computers or know how to use them. ${ }^{43}$ That problem is rapidly disappearing, however. More and more young people, even in low-income communities, are learning how to use computers, and computers are declining in price. Moreover, for the cost of making a few dozen copies of a big EIS, an agency could supply a computer terminal and an internet connection at the nearest library.

Hard copies of EISs should not be eliminated entirely. A copy of each EIS should still be made available at a library or government office for those who cannot or will not use a computer, and hard copies should also be furnished to those relatively few people who will want to review the document closely.

Particular project information in agency files should also be made available electronically. Currently such information is often available only through the Freedom of Information $\mathrm{Act}^{44}$ and its

${ }^{43}$ See generally Mark Warschauer, Demystifying the Digital Divide: The Simple Binary Notion of Technology Haves and Have-Nots Doesn't Quite Compute, SCI. AM., Aug. 2003, at 42.

${ }_{44}$ Freedom of Information Act, 5 U.S.C. $\$ 552$ (2000). 
state counterparts. But it often takes agencies months or even years to comply with requests under these statutes; by the time a member of the public receives the information she has requested, the comment period on the subject project will have long passed.

Finally, if EISs were readily accessible after a project went ahead, it is more likely that both members of the public and government officials would monitor the predictions and commitments made therein. This suggestion has both a technical and a legal dimension. As to the first, there should be some systematic effort to check the predictions made in EISs. Doing so is not as easy as with stocks or sports or Oscars, where anyone can instantly check the results-it will require some physical monitoring. However, a first step would be to use the environmental review process itself as the occasion for such monitoring. That is, if an EIS must examine conditions that were the subject of a prior EIS, part of the process would be to review the older EIS and determine whether its predictions have proven accurate. $^{45}$ Moreover, simply having EISs electronically available would both aid and prompt a shift toward review of past predictions.

The legal dimension of a retrospective examination of an EIS involves the implementation (or lack thereof) of the project proponent's mitigation commitments. Many EISs state that specific actions will be taken to mitigate the environmental impacts. ${ }^{46}$ There is no good mechanism to make sure that those mitigation commitments are actually fulfilled. Anecdotal evidence suggests that often they are not. ${ }^{47}$ Whether mitigation

${ }^{45}$ For example, if New York University (NYU) wants to erect a new building around Washington Square Park, and in order to do so it needs to prepare an EIS because a discretionary governmental action is involved, NYU should be required to look at old EISs for other buildings nearby, see what predictions they made, and see how closely today's reality reflects those predictions. That way the authors of the new EIS will know if employing the same methodologies used the last time will be sufficient, or if they have to devise new methods.

${ }^{46}$ Examples include the requirement to restore wetlands disturbed by a construction project; adjust the timing of certain traffic signals; or maintain a building's plaza area for public use.

$47 C f$. Jerold S. Kayden et al., Privately Owned Public Space: The NEW YORK CITY EXPERIENCE 20-41 (2000) (demonstrating that many of the public plazas created by developers in exchange for the right to erect larger buildings have fallen into disrepair or were not fully opened to public use as required). See generally D.P. Wallace \& J.S. Shalkowski, Post-National 
commitments are administratively or judicially enforceable is beyond the scope of this Article. ${ }^{48}$ However, procedures for monitoring and enforcing such commitments make sense. Of course, one indispensable aspect of any such procedure is readily available information about what commitments have been made. Having EISs accessible and searchable in electronic format would go far towards making this possible. Indeed, it would not be difficult to create a separate database of mitigation commitments; the database could then be used by CEQ or the state environmental agency, as the case may be, to determine whether those commitments were in fact implemented.

\section{Current Practice}

The advantages of online distribution of environmental documents have not been lost on all state and federal agencies. While the practice remains ad hoc, haphazard, and disappointingly limited, a number of agencies have started to post EISs and comparable documents to their websites.

At the federal level, the Department of Energy (DOE) is at the forefront in this regard and is something of a model. DOE has been posting environmental documents on its website since 1994, when its Office of NEPA Policy and Compliance set up the federal government's first NEPA website. ${ }^{49}$ DOE's website contains an

Environmental Policy Act Monitoring of Environmental Impacts and Mitigation Commitments, in TRANSPORTATION RESEARCH RECORD No. 1626, at 31 (1998). Indeed, it has been our experience that the mitigation commitments for different projects sometimes directly conflict. For example, it is common for projects in New York that will create localized traffic congestion to be accompanied by pledges to alter the timing of the nearby traffic signals as a means of reducing that congestion. See, e.g., Wilkinson v. Planning Bd. of Thompson, 680 N.Y.S.2d 710, 712-13 (N.Y. App. Div. 1998); Pyramid Crossgates Co., DEC Project No. 401-0113, 1981 N.Y. ENV LEXIS 27, at *6-7 (N.Y. Dep't of Envtl. Conserv. 1981). In reality the pledges for different projects are often inconsistent with each other. For example, while some may require more green light time for north-south traffic, others may require more green light time for east-west traffic - there is no adequate mechanism for monitoring the promises to alter nearby traffic flows or make sure they are consistent and obeyed.

48 For a good discussion of these issues, see Thomas O. McGarity, Judicial Enforcement of NEPA-Inspired Promises, 20 ENVTL. L. 569 (1990).

49 E-mail from Eric Cohen, DOE, to Michael Gerrard, Partner, Arnold \& Porter (July 25, 2003) (on file with author) [hereinafter Cohen e-mail]. See Office of NEPA Policy and Compliance, DOE, National Environmental Policy Act Program, at http://tis.eh.doe.gov/nepa (last visited Dec. 29, 2003). Exactly what drove the DOE's unusual enthusiasm for computer access is somewhat 
impressive amount of NEPA information-some general and some specific to the agency - in addition to electronic copies of a wide range of environmental documents. One agency official explains:

[t]he purpose of web-publishing NEPA documents and maintaining the DOE NEPA Web site is to foster efficiency in the Department's implementation of the NEPA process, so that the process is more useful to decision makers and the public. Timely posting of NEPA documents not only helps the public to participate in the NEPA process (e.g., to comment on a draft document), but also helps DOE and other agencies in preparing new NEPA documents. ${ }^{50}$

Under DOE's internal NEPA policy, set out in DOE Order $451.1 \mathrm{~B}$, the "NEPA Compliance Officer" responsible for any given project must provide the central Office of NEPA Policy and Compliance "promptly-generally, within two weeks of their

unclear. It occurred during a time of general renewed commitment to NEPA at the Department, following a period in which DOE was often accused of maintaining a perfunctory, dismissive, "pseudo-NEPA" program. See NAT'L ACAD. Pub. Admin., Managing NEPA at the Department of EnERgy (1998), http://tis.eh.doe.gov/nepa/process/napa_rep/napa_rep.html.

During the 1990's, Secretaries of Energy James Watkins and Hazel O'Leary undertook NEPA obligations with new vigor and seriousness. This Article speculates that the confluence of agency heads with a general commitment to transparency, the political need to distance the Department from its unhappy past, the resulting willingness to embrace rather than flee NEPA obligations, and the exciting technological developments of the mid- to late1990 s combined to lead DOE to the forefront here.

Secretary O'Leary issued a Policy on Public Participation in 1994, just when the Department initiated its NEPA website, that did not mention the website specifically. See DOE, Public Participation, DOE Policy No. P 1210.1 (1994), http://www.directives.doe.gov/pdfs/doe/doetext/oldord/1210/ p12101.pdf. Yet, in an accompanying memorandum, O'Leary stated that the "Department will work to establish, announce, and manage topical data bases of reliable, timely information available to the public through telephone and computer access." Memorandum from Hazel O'Leary, Secretary of Energy, to All DOE Employees 3 (July 29, 1994) (on file with author) ("Regarding Guidance on Implementation of the Department's Public Participation Policy"). The Department's so-called "Gold Book," which first appeared in December 1994, endorses the use of "computer bulletin boards, e-mail, Internet, and similar forms of communication to provide members of the public that use this medium with easy, inexpensive access to information about DOE activities, including meetings and availability of documents," noting that "[t]o this end, the DOE NEPA Website was created on the World Wide Web to make the NEPA process more useful to decision-makers and the public." OFFICE OF NEPA POLICY AND assistance, DOE, Effective Public Participation Under the National ENVIRONMENTAL POLICY ACT (2d ed. 1998), http://tis.eh.doe.gov/nepa/tools/ guidance/pubpart2.html.

50 Cohen e-mail, supra note 49. 
availability-five copies and one electronic file" of an EA, proposed FONSI, DEIS or FEIS, ROD, and mitigation action plan and corresponding mitigation report. ${ }^{51}$ The Order does not explicitly require that the electronic version of these documents be posted to the agency's website, but that has long been the practice. While access to DOE documents has been restricted since September 11, 2001, the site remains a striking example of the advantages of using the web to make environmental documents available.

Other federal agencies have not done as well. Numerous individual EISs can be found on the web, ${ }^{52}$ but still only a tiny portion of the thirty thousand that have been prepared over the last three decades, ${ }^{53}$ and no other agency has equaled DOE's systematic and comprehensive effort.

At the state level, California seems to have taken most advantage of the web. For example, the California Water Transit Authority has posted the Environmental Impact Report (the state equivalent of an EIS) for proposed expansion of ferry service in the San Francisco Bay area. ${ }^{54}$ The state Department of Transportation (Caltrans) posts environmental documents in both

51 Doe, National Environmental Policy act Compliance Program 57, DOE Order No. O 451.1B (2001), http://www.directives.doe.gov/pdfs/doe/ doetext/neword/451/o4511bc1.pdf.

52 See, e.g., FHWA, DOT, Boulder City/US 93 Corridor Project: DrafT ENVIRONMENTAL IMPACT STATEMENT AND SECTION 4(F) EVAluation (2002), http://www.bouldercitystudy.com/deistoc.html; FHWA, DOT, DRAFT ENVIRONMENTAL IMPACT STATEMENT, DRAFT SECTION 4(F) STATEMENT: WYOMING FOREST HIGHWAY 4, U.S. 212 (KP 39.5 TO KP 69.4), THE BEARTOOTH HIGHWAY, PARK COUNTY, WYOMING (2002), http://www.cflhd.gov/projects/wy/ beartooth/DEIS/DEIS.pdf; FOREST SERV., DEP'T OF AGRIC., SIERRA NEVADA FOREST PlaN AMENDMENT: DRAFT SUPPLEMENTAL ENVIRONMENTAL IMPACT STATEMENT (2003), http://www.fs.fed.us/r5/snfpa/draft-seis/pdf/printing.pdf; Forest SERV., DEP'T OF AGRIC., READER's GuIDE TO THE SierRA NEVADA FRAMEWORK ENVIRONMENTAL IMPACT STATEMENT (n.d.), http://www.fs.fed.us/ r5/snfpa/library/archives/feis/index.htm; SurfaCE TranSP. BD., POWDER RIVER BASIN EXPANSION PROJECT: FINAL ENVIRONMENTAL IMPACT STATEMENT (2001), http://www.stb.dot.gov/eis/dme/dme_final_eis.htm; DEP'T OF THE AIR FORCE, FINAL ENVIRONMENTAL ASSESSMENTT FOR U.S. AIR FORCE QUICK REACTION LAUNCH VEHICLE PROGRAM (2001), http://ast.faa.gov/lrra/environmental/coop/ qrlv/QrlvEaF.pdf.

53 Karkkainen, supra note 13, at 905 n.6.

54 See Water Transit Auth., Final Program Environmental Impact Report: EXPANSION OF FERry Transit SERVICE IN THE SAN Francisco Bay AREA (2003), http://www.watertransit.org/pubs/eir/ProgramEIR.pdf. 
HTML and PDF format, arranged throughout the site by district. ${ }^{55}$ The California Resources Agency has established the California Environmental Resources Evaluation System (CERES), which it describes as "an information system developed ... to facilitate access to a variety of electronic data describing California's rich and diverse environments." 56 A number of environmental documents can be found on the website, along with a huge amount of legal, technical, and geographic information. While the cataloguing of environmental documents is somewhat haphazard and incomplete, the website is an extraordinary step in the right direction.

The closest New York has come to following California's lead is at the website of the New York Department of Public Service, which includes completed applications for building major new electric generating plants. ${ }^{57}$ The Lower Manhattan Development Corporation, a state agency that is planning the redevelopment of the area devastated by the attacks of September 11,2001 , is now preparing an EIS and posting the key documents on its website. ${ }^{58}$ DEC has slowly been expanding its website to include more useful environmental information. For example, it recently established a web page concerning ongoing site investigation and remediation efforts at the contaminated site of a former IBM facility in Endicott, New York. ${ }^{59}$ It may be that in the

55 See, e.g., Caltrans, District 7 Environmental Documents On-Line, at http://www.dot.ca.gov/dist07/pubs/enviro_docs.shtml (last visited Dec. 23, 2003).

56 CERES, Welcome to CERES, at http://ceres.ca.gov/ (last visited Dec. 23, 2003).

57 These applications contain EIS-level information. See N.Y. State Pub. Serv. Comm'n, The New York State Board on Electric Generation Siting and the Environment, at http://www.dps.state.ny.us/articlex.htm (last visited Nov. 25, 2003).

58 See lower Manhattan Dev. Corp., Final Scope: World Trade CENTER MEMORIAL AND REDEVElopMENT Plan GeneriC ENVIRONMENTAL IMPACT STATEMENT (2003), http://www.renewnyc.com/content/pdfs/ WTC_GEIS_Final_Scope.pdf.

${ }^{59}$ See DEC, Village of Endicott Vapor Migration Project Information Site, at http://www.dec.state.ny.us/website/dshm/sldwaste/endicottfacts.htm (last visited Dec. 23, 2003).

Some states require that environmental site assessments be submitted to the government. In conjunction with the effort to put EISs on the web, there should also be a requirement to submit in electronic form all environmental site assessments that go to the government (This Article does not advocate that all such assessments be required to go the government, for that would inhibit many 
foreseeable future DEC will significantly expand its reliance on electronic dissemination of EISs. Just this year the Department adopted a policy on "environmental justice and permitting," under which DEC staff is to draft "regulations to require the electronic submission of environmental impact statements."60 Some municipalities are posting EISs on the web, ${ }^{61}$ and a law adopted by the New York City Council in 2003 will require that EISs prepared by or for city agencies be posted on the web. ${ }^{62}$ At present, however, electronic dissemination of environmental documents remains quite underdeveloped in New York.

\section{II \\ LEGAL REQUIREMENTS}

Not only should agencies be posting EISs to the web, they are required to do so under existing law. This Article focuses on federal law; however certain state and municipal requirements can also be read to impose an obligation to post environmental documents on the web.

\section{A. National Environmental Policy Act}

In its typically bare-bones fashion, NEPA itself is rather silent

parties from preparing them; but if such assessments do go to the government, they should be put online unless legitimate considerations of confidentiality dictate otherwise.).

${ }^{60}$ DEC, ENVIRonmental Justice AND PERmitTing pt. III, sec. B, para. 13, DEC Policy No. CP-29 (2003), http://www.dec.state.ny.us/website/ej/ ejpolicy.html.

${ }^{61}$ For example, White Plains, New York, posted an urban redevelopment project draft EIS to its website. See City of White Plains Common Council, 221 Main Street Redevelopment, City of White Plains, New York: Draft ENVIRONMENTAL STATEMENT (2003), http://www.cityofwhiteplains.com/ news/releases/221 main/221 main.htm.

62 N.Y. CiTy LoCal LAW No. 11 of $2003, \S 2$, Council Int. No. 119-A (amending $\S 1133(a)$ of the New York City Charter to provide that the Department of Records and Information Services shall make "available to the public on or through the department's website" every agency "report, document, study and publication" that is required by local, state, or federal law to be published, issued, or transmitted to the City Council or the Mayor), http://www.council.nyc.ny.us/pdf_files/bills/law03011.pdf; see also COMM. ON Governmental Operations \& Select Comm. ON TeCh. in Gov'T, The COUNCIL OF THE CITY OF N.Y., BRIEFING PAPER OF THE INFRASTRUCTURE DIVISION AND GOVERNMENT AFFAIRS DIVISION (2002), http://www.council.nyc.ny.us/attachments/55892.htm. 
on the question of distributing an EIS, though not totally so. It requires that an EIS "shall be made available to ... the public as provided by" the Freedom of Information Act (FOIA). ${ }^{63}$ This sentence can be read in two subtly different ways. First, it might be broken in two: the agency shall make EISs available to the public and in doing so shall comply with, and benefit from the exemptions contained in, FOIA. This is the reading it has generally received and is reflected in, among other things, the CEQ regulations. ${ }^{64}$ Alternatively, the statute might be read to mean that the agency's obligation to provide EISs to the public is no more and no less than its obligation to provide other "records" under FOIA. Under this reading, the importance of this provision is only that it establishes that an EIS is an agency "record" for FOIA purposes, and all questions of availability and distribution are FOIA questions, not NEPA questions. The first of these readings is addressed in this Part; the second is considered below. ${ }^{65}$

As noted, the general understanding is that NEPA itself imposes an obligation on agencies to "make available" EISs to the public. The CEQ regulations elaborate on this obligation in several ways. First, an agency is required to "circulate the entire draft and final [EIS]." If the EIS is especially lengthy, the agency need "circulate" only the summary but must still provide the entire document to involved agencies, the applicant (if any), anyone who submitted extensive comments, and anyone who asks for a copy. ${ }^{67}$ In addition, EISs, comments thereon, and underlying documents must be made "available to the public pursuant to the provisions of the Freedom of Information Act." done free of charge if practicable, and in any event at a fee no more than the actual duplication costs. ${ }^{69}$

6342 U.S.C. $\$ 4332(2)(C)(2000)$.

${ }^{64}$ See 40 C.F.R. $\$ \$ 1502.19$ (requiring circulation of a DEIS and a FEIS to, among others, any private party who requests a copy), 1506.6 (detailing agency obligations to involve and inform the public) (2003).

${ }^{65}$ See infra Part II.C.

6640 C.F.R. $\$ 1502.19$.

67 Id.

${ }^{68}$ Id. $\S 1506.6(\mathrm{f})$.

69 Id. This section reads:

[a]gencies shall... [m]ake environmental impact statements, the comments received, and any underlying documents available to the public pursuant to the provisions of the Freedom of Information Act ( 5 U.S.C. 552), without regard to the exclusion for interagency memoranda where such memoranda transmit comments of Federal 
The regulations are authorized by and reflect the requirements of President Nixon's Executive Order 11,514. This Order, promulgated just months after NEPA's enactment and still in force, also imposes an obligation on agencies to make environmental documents available. The Order requires agencies to

[d]evelop procedures to ensure the fullest practicable provision of timely public information and understanding of Federal plans and programs with environmental impact in order to obtain the view of interested parties. These processes shall include, whenever appropriate, provision for public hearings, and shall provide the public with relevant information, including information on alternative courses of action. ${ }^{70}$

Finally, individual agencies' NEPA regulations ${ }^{71}$ routinely provide that DEISs and FEISs be "made available." For example, FHWA requires that DEISs "shall be made available to the public."72 FEISs are to be "made available" as well and "should also be made available for public review at institutions such as local government offices, libraries, and schools, as appropriate., ${ }^{, 73}$

agencies on the environmental impact of the proposed action. Materials to be made available to the public shall be provided to the public without charge to the extent practicable, or at a fee which is not more than the actual costs of reproducing copies required to be sent to other Federal agencies, including the Council.

Id. The requirement of notice and public availability applies to all "environmental documents," which includes EISs, EAs, FONSIs, and Notices of Intent, $i d$. $\S 1508.10$ (definition of "environmental document"), as well as RODs, although the regulations themselves are not explicit with regard to RODs. See CEQ, NEPA's Forty Most Asked Questions \#34a, 46 Fed. Reg. 18,026, 18,036 (Mar. 23, 1981), http://ceq.eh.doe.gov/nepa/regs/40/40p3.htm.

70 Exec. Order No. 11,514, § 2(b), 3 C.F.R. 531, 532 (1971), reprinted in 42 U.S.C.A. $\S 4231$ (West 2003) (emphasis added). This order was amended in technical respects by Exec. Order No. 11,991, 3 C.F.R. 123 (1978).

71 The CEQ regulations anticipate that each agency "shall as necessary adopt procedures to supplement these regulations." 40 C.F.R. $\S 1507.3$ (a).

7223 C.F.R. $\$ 771.123(\mathrm{~g})(2003)$.

73 The regulations provide:

[t] he final EIS shall be transmitted to any persons, organizations, or agencies that made substantive comments on the draft EIS or requested a copy, no later than the time the document is filed with EPA. In the case of lengthy documents, the agency may provide alternative circulation processes in accordance with 40 CFR 1502.19. The applicant shall also publish a notice of availability in local newspapers and make the final EIS available through the mechanism established pursuant to DOT Order 4600.13 which implements Executive Order 12,372. When filed with EPA, the final EIS shall be available for 
In short, under the statute, the regulations, agency interpretations of the regulations, and an Executive Order, agencies must alert the public to the existence of environmental documents and make them available in an effective and timely way. These requirements were not written with electronic documents, let alone the Internet, in mind. The drafters of NEPA and the regulations had in mind the provision of hard copies. To "make available" or to "provide" has always, uncontroversially, meant to have available for review at a public location (e.g., the agency's own offices or a library) or to send a hard copy in the mail. Most attention has instead been focused on giving adequate notice of availability. $^{74}$

What do these requirements amount to in 2003? It is very hard to read them as not requiring the posting of environmental documents to an agency website. Indeed, the real question would seem to be whether hard copies must also be made available, or whether having electronic copies available on the Internet suffices. As the federal government has recognized in other settings, the web is now the most effective, direct, inexpensive, and convenient means for making governmental information "available." 75 In 2003, "to ensure the fullest practicable provision of timely public information"

This claim poses a nice question of "dynamic statutory interpretation." 77 This Article suggests that the statute and regulations require different conduct than they required when adopted and different conduct than their drafters envisioned. However, as an instance of changing statutory meaning, this one is rather mild. The world has changed in ways that the statutory language easily accommodates; in that sense, the "meaning" of that language has not changed at all-only its application has. To use terms common in constitutional interpretive theory, the

public review at the applicant's offices and at appropriate Administration offices. A copy should also be made available for public review at institutions such as local government offices, libraries, and schools, as appropriate.

Id. $\S 771.125(\mathrm{~g})$. See also 10 C.F.R. 1021.313 (2003) (detailing the processes for public review of EISs by the Department of Energy).

${ }_{75}$ See, e.g., 40 C.F.R. $\S 1506.6(\mathrm{~b})$.

75 See generally E-GOVERNMENT STRATEGY, supra note 2.

76 Exec. Order No. 11,514, supra note 70, § 2(b), at 532.

77 See generally WILliAM N. ESKRIDGE, JR., DYNAMIC STATUTORY INTERPRETATION (1994). 
"conception" has changed but the "concept" has remained constant. $^{78}$ The original conception was hard copies on bookshelves that could be sent through what is now called "snail mail." The new conception is electronic copies on websites that can be downloaded through the Internet. In both instances the concept-meaningful public access to particular documents-is identical. The only change is that the new conception serves the concept even better than the old.

Many examples of such shifts can be found in statutory cases. To pick one quite close to home, consider the recent consent decree in Our Children's Earth Foundation v. EPA. ${ }^{79}$ This was a Clean Air Act citizens' suit in which the plaintiff argued that EPA had a legal obligation to "publish" State Implementation Plans (SIPs). ${ }^{80}$ SIPs are notoriously difficult to obtain. There may or may not be an actual volume collecting all the numerous and changing requirements in one place $;^{81}$ if it exists, that volume is likely out of date and can be found only at the offices of the state environmental agency or the regional office of EPA, viewable by appointment. However, $\S 110$ of the Act requires EPA to "assemble and publish a comprehensive document for each State setting forth all requirements of the applicable implementation plan for such State." ${ }^{, 82}$ The plaintiffs in Our Children's Earth

78 The distinction is most closely associated with Ronald Dworkin. See, e.g., RONALD DWORKIN, TAKING RIGHTS SERIOUSLY 135-36 (1977). Dworkin gives the example of defining "cruel and unusual punishment" as prohibited by the Eighth Amendment. He argues that the framers" overall "concept," which involves concerns of basic dignity and reference to contemporary mores, should trump their specific "conception," under which various punishments that we now consider abhorrent were acceptable. The distinction between concept and conception is a good deal less controversial when applied to changing technology than when applied to changing societal values.

79 See Proposed Consent Decree, Clean Air Act Citizen Suit, 68 Fed. Reg. 23,457 (May 2, 2003) (summarizing Our Children's Earth Foundation v. EPA, No. CO3-1705 (N.D. Cal. 2003)).

80 A SIP consists of the accumulation of all state law requirements that in any way limit or affect the emissions or concentrations of air pollutants for which the EPA has established National Ambient Air Quality Standards. Though its requirements are part of state law, a SIP must also satisfy the minimum requirements set forth in the Clean Air Act and must be submitted to the EPA for approval. See 42 U.S.C. $\$ 7410$ (2000).

81 For a discussion of the "indeterminacy" and "obscurity" of SIPs, see William H. RODGERS, JR., ENVIRONMENTAL LAW: Air AND WATER 259-62 (1986).

8242 U.S.C. $\S 7410(\mathrm{~h})(1)$. 
sought injunctive relief requiring such "publication," though the complaint did not request publication in a particular format or location. The case was resolved by a consent decree, in which EPA agreed that it would publish each state's SIP on the web according to a particular schedule. ${ }^{83}$ Obviously, this result does not mean that federal agencies are obligated to post EISs and similar documents to the web. It is a consent decree, from a single district court, under a different statute (and one which uses the stronger word "publish" rather than the weaker term "make available"). Yet, it illustrates how the meaning of a statutory term can easily change in light of evolving technology. When $\S 110$ was adopted in 1970, no one in Congress thought that to "assemble and publish a comprehensive document" meant to post it to the Internet. Three decades later, the plaintiffs in this lawsuit, EPA, and a federal judge all rightly concluded that was a reasonable understanding of the statutory term. The same goes for the requirement in NEPA and related regulations that environmental documents be made available.

\section{B. The Paperwork Reduction Act}

This reading draws further support from the Paperwork Reduction Act (PRA or the Act). ${ }^{84}$ Although primarily concerned with minimizing the paperwork burden on regulated entities and establishing oversight of agency information requests by $\mathrm{OMB}$, the Act also contains some general provisions concerning the management and dissemination of information. ${ }^{85}$ One of Congress' purposes in enacting PRA was to "provide for the dissemination of public information on a timely basis, on equitable terms, and in a manner that promotes the utility of the information to the public and makes effective use of information technology." 86 In particular, the 1995 amendments to the Act require every agency to "ensure that the public has timely and equitable access

83 See Notice of Proposed Consent Decree, supra note 79 , at 23,457 . The Consent Decree was entered on September 16, 2003. E-mail from Helen Kang, Counsel, Our Children's Earth Foundation, to Michael Herz, Professor of Law, Cardozo School of Law, Yeshiva University (Sept. 30, 2003) (on file with author).

${ }_{84}$ Paperwork Reduction Act, 44 U.S.C. $\S \S 3501-3520$ (2000).

85 See generally id. $\$ 3506$

86 Id. $\S 3501(7)$. 
to the agency's public information." "Pu "Public information" is a defined term; it clearly extends to environmental documents. ${ }^{88}$ Such access is to be ensured by, among other things, "dissemination... in an efficient, effective, and economical manner." 89 Given the state of current technology, in most instances posting to a website is, by a wide margin, the most "efficient, effective, and economical manner" in which to disseminate information, and therefore is required by PRA.

OMB, which is charged with implementation of PRA, ${ }^{90}$ has endorsed dissemination of agency information in electronic form, although it has not directly addressed EISs and other environmental documents. OMB Circular A-130, first issued in $1985^{91}$ and revised several times since, "contains the most comprehensive statement of executive branch information policy." "92 Adopted under the authority of PRA, among other statutes, the Circular applies to all federal agencies. As revised in

${ }^{87}$ Paperwork Reduction Act of 1995, Pub. L. No. 104-13, § 2, 109 Stat. 171, 174-75 (codified at 44 USC $\$ 3506(d)(1)$ (2000)).

"Agency" is defined broadly to include "any executive department, military department, Government corporation, Government controlled corporation, or other establishment in the executive branch of the Government (including the Executive Office of the President), or any independent regulatory agency." 44 U.S.C. $\$ 3502(1)$. NEPA's EIS requirement applies to "all agencies of the federal government." 42 U.S.C. $\S 4332(2)$ (emphasis added). While NEPA does not otherwise define the "agencies" to which it applies, the "all" indicates that a broad reading is appropriate and that is what it has received. See 40 C.F.R. $\$ 1508.12$ (2003) (defining "federal agency" to include all agencies of the federal government, but not Congress, the Judiciary, the President, or those who perform staff functions for the President in the Executive Office). No agency subject to NEPA is exempt from the Paperwork Reduction Act, with the possible exception of the Federal Election Commission. 44 U.S.C. $\S 3502(1)(B)$.

${ }^{88}$ See 44 U.S.C. $\$ 3502(12)$ (defining "public information" as "any information, regardless of form or format, that an agency discloses, disseminates, or makes available to the public").

${ }^{89}$ Id. $\$ 3506(\mathrm{~d})(1)(\mathrm{C})$. One might have hoped that agencies did not require a legal mandate to operate in an efficient, effective, and economical manner. In any event, they have such a mandate.

${ }_{90}$ Indeed, the Office of Information and Regulatory Affairs, charged with overseeing the implementation, was created by this legislation. See Paperwork Reduction Act of 1980, Pub. L. No. 96-511, § 2(a), 94 Stat. 2814 (codified as amended at 44 U.S.C. $\S 3503($ a) (2000)).

91 Management of Federal Information Resources, 50 Fed. Reg. 52,730 (Dec. 24, 1985) (issuing OMB Circular A-130).

92 Henry H. Perritt, Jr., Electronic Freedom of Information, 50 ADMIN. L. REV. 391, 400 (1998). 
$1993,{ }^{93}$ the Circular provides:

(8) Electronic Information Dissemination. Agencies shall use electronic media and formats, including public networks, as appropriate and within budgetary constraints, in order to make government information more easily accessible and useful to the public. The use of electronic media and formats for information dissemination is appropriate under the following conditions:

(a) The agency develops and maintains the information electronically;

(b) Electronic media or formats are practical and cost effective ways to provide public access to a large, highly detailed volume of information;

(c) The agency disseminates the product frequently;

(d) The agency knows a substantial portion of users have ready access to the necessary information technology and training to use electronic information dissemination products;

(e) A change to electronic dissemination, as the sole means of disseminating the product, will not impose substantial acquisition or training costs on users, especially State and local governments and small business entities. ${ }^{94}$

This reads like a direct mandate to agencies to post EISs to the web. It seems there are only two arguments to the contrary. First, the entire obligation is subject to the large qualifier at the outset: "as appropriate and within budgetary constraints." For the reasons given above, of course, electronic dissemination is more than "appropriate," and not particularly burdensome financially. Second, electronic dissemination is required only if the agency already develops and maintains the information electronically. This condition is met simply because EISs are prepared using word processing software on computers. While there is clearly no obligation here to take old, paper EISs and convert them into electronic format, any newer document that sits on a hard drive, CD ROM, or floppy disk has been "developed" and is being "maintained" "electronically."

93 See Management of Federal Information Resources, 58 Fed. Reg. 36,068 (July 2, 1993) (revising Circular A-130).

94 Id. at 36,073 . 


\section{The Electronic Freedom of Information Act}

NEPA expressly makes the dissemination of EISs subject to FOIA: "[c]opies of such statement ... shall be made available ... to the public as provided by section 552 of Title 5." 95 In effect, then, NEPA itself defines an EIS as a "record" subject to FOIA. That means that, unless subject to one of the exemptions from disclosure, EISs must be provided on request to any person who asks. ${ }^{96}$ But FOIA does more than require that records be provided to those who ask. As amended by the 1996 Electronic Freedom of Information Act (EFOIA), ${ }^{97}$ FOIA requires certain documents to be posted to the web as part of "electronic reading rooms." Indeed, as one observer has written, the basic thrust of EFOIA was to make the shift from a system in which requesters endure lengthy delays while waiting for paper copies of records "to a model in which agencies anticipate requests and act to make records (and information on how to find additional records) available over online systems." 99 It is clear that this requirement applies to all, or virtually all, environmental documents.

FOIA divides agency records into three categories. Some items, known as "a(1) material," which include descriptions of

9542 U.S.C. $\S 4332(2)(C)(2000)$. While this provision only explicitly applies to FEISs, CEQ and other agency regulations and caselaw, supported by common sense, also treat EAs, FONSIs, and DEISs as equally subject to $\S 552$.

965 U.S.C. $\& 552(\mathrm{a})(3)(\mathrm{A})$ (imposing obligation to provide requested records), § 552(b) (listing exemptions) (2000). See also 32 C.F.R. $\S 775.5$ (2003) (Department of Defense regulations concerning nondisclosure of classified information in an EIS); Weinberger v. Catholic Action of Haw./Peace Educ. Project, 454 U.S. 139 (1981) (applying FOIA's national security exemption to release of information in EIS). It should be noted that, anecdotally, after September 11, 2001, many federal and state agencies removed a considerable amount of environmental information from their web pages. The wisdom and necessity of these controversial actions are beyond the scope of this Article.

${ }^{97}$ Electronic Freedom of Information Act Amendments of 1996, Pub. L. No. 104-231, 110 Stat. 3048 (codified at 5 U.S.C. $\$ 552$ (2000)).

98 See, e.g., Office of Freedom of Info. and Privacy Act Operations, Sec. \& Exch. Comm'n, Conventional and Electronic Reading Rooms, at http://www.sec.gov/foia/efoiapg.htm (last visited Dec. 23, 2003); Dep't of Agric., FOIA Electronic Reading Room, at http://www.usda.gov/news/foia/ room.htm (last visited Dec. 23, 2003).

99 Michael Tankersley, Opening Drawers: A Requester's Guide To the Electronic Freedom of Information Act Amendments, LEGAL TIMES, May 19, 1997, at 29. See generally Michael E. Tankersley, How the Electronic Freedom of Information Act Amendments of 1996 Update Public Access for the Information Age, 50 ADMIN. L.J. 421 (1998). 
agency organization and proposed and final regulations, must be published in the Federal Register. ${ }^{100}$ A second category, "a(2) material," consists of other important documents that are likely to be the subject of public requests, such as orders in agency adjudications and staff manuals and policy statements. ${ }^{101}$ These need not be published but must be made available for public inspection and copying. Agencies have established reading rooms containing these records. All other records are classified as " $\mathrm{a}(3)$ material" and must be provided upon request. ${ }^{102}$

EFOIA expanded the reading room concept to require agencies to provide electronic access to all "(a)(2) material" that was created after November $1,1996 .{ }^{103}$ In short, if environmental documents are "records," created after November 1, 1996, of the sort that are covered by $\S 552(a)(2)$, then they must be made available in electronic format. ${ }^{104}$

Environmental documents are clearly "records"-NEPA itself makes them so. Prior to 1996, however, they were generally seen as "(a)(3) material." 105 Thus, FOIA itself imposed no affirmative duty on the agency to provide or disseminate EISs unless and until it received a request for them. With the 1996 amendments, however, the scope of $\S 552(a)(2)$ changed dramatically; it now extends to:

all records, regardless of form or format, which have been released to any person [who made a specific request therefore] and which, because of the nature of their subject matter, the agency determines have become or are likely to become the

1005 U.S.C. $\S 552(a)(1)$ (requiring each agency to publish in the Federal Register descriptions of the agency, statements of its general policies, rules of procedure, and substantive rules and statements of general policy of general applicability).

${ }_{101} I d . \S 552(\mathrm{a})(2)$ (requiring each agency to make available for inspection and copying final opinions in agency adjudications, statements of policy and interpretations that were not published in the Federal Register, and staff manuals).

${ }^{102}$ Id. $\S 552(\mathrm{a})(3)$.

103 Id. $\S 552(\mathrm{a})(2)$ ("[E]ach agency shall make such records available, including by computer telecommunications, or, if computer telecommunications means have not been established by the agency, by other electronic means.").

104 The statute's language indicates that "electronic format" means not only posted to the web but also on floppy disks or CD-ROMs. However, the latter alternative is available only if an agency has not established "computer telecommunications." Id. At this point, all federal agencies have done so.

105 See Russell L. Weaver, Judicial Interpretation of Administrative Regulations: An Overview, 53 U. ClN. L. REV. 681, 715-16 (1984). 
subject of subsequent requests for substantially the same records. ${ }^{106}$

In other words, anything that has been or will be requested three times-the initial request plus subsequent "requests," plural-must be made available for inspection and copying. Furthermore, any material that must be made available for inspection and copying and was created after November 1996 must be made available electronically. Therefore, any environmental document that has been, or can be expected to be, asked for by three or more people must be posted to the web. It would be the rare EIS that would not be the subject of three requests. ${ }^{107}$

Note that this provision imposes no burden on agencies to place pre-1996 EISs in electronic reading rooms. In addition, the requirement rests not on the nature of an EIS but on the fact that it is or is likely to be requested by at least three people. Therefore, if there were an EIS that the agency would expect to be requested by only two or fewer people, then there would be no need to make it electronically available under EFOIA.

\section{The E-Government Act of 2002}

With some fanfare and grand aspirations, but uncertain effects, the E-Government Act of 2002 aims to bring the federal government into the electronic age. ${ }^{108}$ The Act established a new Office of Electronic Government within OMB, headed by a Senate-approved administrator, ${ }^{109}$ and requires or encourages government use of the Internet in a wide variety of settings. Section 206 of the bill applies to regulatory agencies. In addition to requiring electronic commenting and docketing in notice-andcomment rulemakings, the new provision imposes a general obligation to post certain documents on the web. The relevant provision states:

\footnotetext{
1065 U.S.C. $\$ 552(a)(2)(D)$ (emphasis added).

107 The Forest Service provides an example of an agency posting environmental documents to its EFOIA electronic reading room, apparently in agreement with the foregoing arguments. See Forest Serv., Dep't of Agric., Kaibab National Forest Frequently Requested Documents: Environmental Documentation, at http://www.fs.fed.us $/ \mathrm{r} 3 / \mathrm{kai} /$ business $/$ manage_ea.html (last visited Dec. 23, 2003).

108 E-Government Act of 2002, Pub. L. No. 107-347, 116 Stat. 2899 (codified in scattered sections of 44 U.S.C.A. (West 2003)).

10944 U.S.C.A. $\$ 3602$.
} 
(b) INFORMATION PROVIDED BY AGENCIES ONLINETo the extent practicable as determined by the agency in consultation with the Director, each agency (as defined under section 551 of title 5 , United States Code) shall ensure that a publicly accessible Federal Government web site includes all information about that agency required to be published in the Federal Register under paragraphs (1) and (2) of section 552(a) of title 5, United States Code. ${ }^{110}$

This Article suggests that the new provision requires agencies to post EISs, though the issue is uncertain.

This is an extraordinarily poorly drafted provision, which gives rise to two ambiguities in particular. First, it only requires posting of "information about the agency." Read narrowly, that would include only such things as staff manuals, memoranda of understanding, or other items that tell the reader something about the agency, its personnel, and its means of operation. On the other hand, any document that an agency produces provides, directly or indirectly, "information about the agency." Thus, a broad reading would treat "information about the agency" as synonymous with "documents" or "material" or, simply, "information." The latter reading is preferable. For one thing, most material that is covered by $\S 552(a)(1)$ and $\S 552(a)(2)$ is not "information about the agency" in the narrow sense. Second, the general purposes and thrust of the Act support broader coverage, and there is no apparent justification for limiting section 206(b) to the organization chart and the agency phone directory. ${ }^{111}$

Finally, an EIS arguably constitutes "information about the

110 Id. $\S 3501$

III A middle reading would be that "information about the agency" refers to material about rulemaking. This middle reading is suggested by the fact that the rest of section 206 concerns agency rulemakings. It also draws some support from the legislative history. The section-by-section guide to the Senate bill which became the E-Government Act notes that section 206 "[r]equires that agencies post on their websites all information about the agencies' regulatory proceedings that is required to be published in the Federal Register." SENATE COMM. ON GovTl. AFFS., E-GovernMENT ACT OF 2001: SECTION BY SECTION ANALYSIS 3 (n.d.) (emphasis added), http://www.senate.gov/ gov_affairs/ egovsectionbysection.pdf. However, this reading is inconsistent with the actual text of the provision and with its title (which is "regulatory agencies," not, for example, "agency rulemaking"). In addition, it renders section 206(b) completely redundant with 206(d), which requires maintenance of an electronic docket in the context of rulemaking. E-Government Act $\S 206(d)$ (codified at 44 U.S.C.A. $\S 3501)$. For the section to serve any function, it must require posting of documents other than those that are part of the rulemaking. 
agency" even under a relatively narrow reading. By definition, an EIS is a thorough consideration of a project or other undertaking that the agency plans-or that private entities hope the agency will allow to happen. It is a detailed description and analysis of what the agency is up to. That is "information about the agency."

The second drafting defect of section 206(b) is that it applies only to information that is "required to be published in the Federal Register under paragraphs (1) and (2) of section 552(a) of title 5, United States Code." The problem here is that $\S 552(\mathrm{a})(2)$ does not require anything to be published in the Federal Register; only (a)(1) does that. As discussed above, (a)(2) materials need only be made available. Thus, information "required to be published in the Federal Register under paragraph ... 2 of section 552(a)" is the null set. Again, two readings are possible here. The literal, and narrower, reading would make this section only applicable to items required to be published in the Federal Register. The broader reading would require posting to an agency website of any material covered by either $\S 552(\mathrm{a})(1)$ or $\S 552(\mathrm{a})(2)$. The second reading is preferable. First, under the literal reading, the reference to $\S$ $552(a)(2)$ is meaningless - it serves no function. Second, why would Congress have referred to $\S 552(a)(2)$ at all if it did not expect the obligation to extend to the materials covered thereby?

The drafting history is inconclusive. The original bills in both the House and the Senate clearly would have required website posting of both $\S 552(\mathrm{a})(1)$ and $\S 552(\mathrm{a})(2)$ material. Each contained an identical provision that would have required agencies to:

(2) post on the web site all information-

(A) required to be published in the Federal Register under section 552(a)(1) of title 5, United States Code; and

(B) made available for public inspection and copying under section 552(a) (2) and (5) of title 5, United States Code, after the effective date of this section.

The Senate bill was modified in committee and the reference to subsections (a)(2) and (a)(5) dropped. Thus, as reported out of Committee, and as passed by the Senate, Senate Bill 803 required only that each agency website include "all information about that agency required to be published in the Federal Register under

112 H.R. 2458, 107th Cong. $\S 206(\mathrm{a})(2)$ (2001) (as introduced); S. 803, 107th Cong. $\S 206(a)(2)$ (2001) (as introduced). 
section 552(a)(1)."113 On the House side, the provision was also rewritten in committee, with the original clear language replaced by the opaque version that was ultimately passed. It is certainly possible that the House drafters were trying to do what their Senate counterparts did, and were just careless. ${ }^{114}$ It is also possible that the drafters were trying to stick with the original requirement and do so in a more condensed and elegant text.

If Section 206(b) of the E-Government Act applies to material that must be made available under $\S 552(a)(2)$, and not only material that must be published in the Federal Register under $\S$ 552(a)(1), then it requires that EISs be posted to the agency's website. As illustrated in the previous section, EISs are indeed covered by $\S 552(\mathrm{a})(2)$ - or at least the huge majority is - since the EISs are records that predictably will be requested by at least three persons.

Even if section 206(b) applies only to material that must be published in the Federal Register, another provision of the EGovernment Act requires posting of $\S 552(\mathrm{a})(2)$ material in the near future. Section 207 calls on the Director of OMB to establish an "Interagency Committee on Government Information." 15 The Committee will develop a set of policies and guidelines for agency websites, which will be followed by agency-specific determinations of what information will be posted to the web. For all the reasons discussed in this Article, the Committee and individual agencies should ensure that EISs and other environmental documents are made available on the web.

Section 207 also imposes a handful of direct requirements for agency websites. By December 17, 2004, OMB is to issue "guidance" that requires each agency website to include links to "(i) descriptions of the mission and statutory authority of the agency; (ii) information made available to the public under subsections (a)(1) and (b) of section $552 \ldots$; (iii) information about the organizational structure of the agency;" and (iv) the

113 S. 803 , 107th Cong. $\$ 206$ (b) (2002) (as passed by Senate). Thus, the final Senate bill was clearly limited only to materials required to be published in the Federal Register.

114 The House Report suggests, barely, that this is the case. Its description of the bill states that agencies must "[i]nclude in a publicly accessible website all information required to be published in the Federal Register under the Freedom of Information Act, at 5 U.S.C. 552(a)(1) \& (2)." H. Rep. 107-787, pt. 1, at 69 (2002), reprinted in 2002 U.S.C.C.A.N. 1880, 1904.

115 E-Government Act of $2002 \S 207$ (c)(1) (codified at 44 U.S.C.A. $\S 3501$ ). 
agency's strategic plan. ${ }^{116}$ Like section 206 , this section also seems to contain a drafting error. Here the problem is the reference to information "made available" under "subsections (a)(1) and (b)." The problem is that $\S 552$ (b) does not require any information to be made available to anyone; to the contrary, it contains the exemptions from FOIA's general requirement to provide records upon request. ${ }^{117}$ Read charitably, this provision requires posting of nonexempt $\S 552(\mathrm{a})(1)$ material. Under this reading, it has no applications to EISs. However, if that is all it means, it would seem to duplicate section 206, which requires that $\S 552(a)(1)$ information be posted to a website. Nor is there any possible justification for limiting agency's postings to only that tiny fraction of agency documents that are posted in the Federal Register. It seems more likely that "(b)" is a typographical or drafting error and should read "(2)." Such an error is certainly imaginable, and a reference to subsection (a)(2) makes much more sense in context than a reference to subsection (b). The provision seems a good candidate for a Corrections Day amendment.

So read, section 207 requires posting of all $\S 552(\mathrm{a})(2)$ material, pursuant to OMB guidelines, beginning in December 2004. ${ }^{118}$

\section{CONCLUSION}

By the time this Article is published and, appropriately, posted to the website of the NYU Environmental Law Journal, ${ }^{119}$ much of what it says may be obsolete. Technology generally and use of the Internet in particular are quickly moving targets. The

116 Id. $\S 207(\mathrm{f})(1)(\mathrm{A})$. OMB's guidance must be issued "[n] ot later than 2 years after the effective date of this title." Id. Most of title II of the Act becomes effective 120 days after enactment, $i d$. $\S$ 402(a)(1), but section 207 becomes effective upon enactment. Id. $\S$ 402(a)(2). President Bush signed the EGovernment Act into law on December 17, 2002.

1175 U.S.C. $§ 552(b)(2000)$ (listing nine types of matters to which " $[\mathrm{t}] \mathrm{his}$ section does not apply").

118 Such an understanding of section 207(f) does undercut our argument that section $206(\mathrm{~b})$ requires posting of (a)(2) material. One reading that would give each section independent meaning and effect would be that section 206(b) requires agencies to post all (a)(1) material 120 days after enactment (though only to the extent practicable), and then section $207(\mathrm{f})$ requires posting of all (a)(2) material two years after enactment.

119 NYU Envtl. Law Journal, Issue Archive, at http://www.law.nyu.edu/ journals/envtllaw/issues/index.html (last visited Dec. 23, 2003). 
CEQ Task Force, which is currently engaged in an open-ended consideration of possible NEPA reforms, ${ }^{120}$ has received extensive comments on issues concerning technology. ${ }^{121}$ It is without doubt that over time the NEPA process will extensively integrate new technologies in ways that go beyond what this Article has described. The time will come, for example, when geographic information system techniques will allow a user to type in a particular location and be presented with comprehensive environmental data for that location, including a list of and links to all EISs previously prepared for the area, a description of the predictions those EISs made about future conditions, and a database of mitigation commitments.

The first step is to get all environmental documents onto the web. For the policy and legal reasons set out above, that should happen now. The above measures, involving use of today's information technologies, will result in an environmental review process that is more effective, democratic, efficient, and, ultimately, protective of the environment.

120 See generally National Environmental Policy Act Task Force, 67 Fed. Reg. 45,510 (July 9, 2002) (notice of establishment of task force). See also James L. Connaughton, Modernizing the National Environmental Policy Act: Back To the Future, 12 N.Y.U. ENVTL. L.J. 1, 7-12 (2003).

121 CONTENT ANALYSIS TEAM, DeP'T OF Agric., CEQ TASK Force REVIEW of THE NEPA PRocess: SuMmary OF Public COMMENT ch. 2 (2002) (summarizing numerous public comments regarding technology, information management, and information security), http://ceq.eh.doe.gov/ntf/catreport/ ceq_ch2.pdf. 